\title{
特集：アフリカ・モラル・エコノミーの現代的視角
}

\section{モラル・エコノミー論からみた アフリカ農民経済}

一アフリカと東南アジアをめぐる農民論比較のこころみー

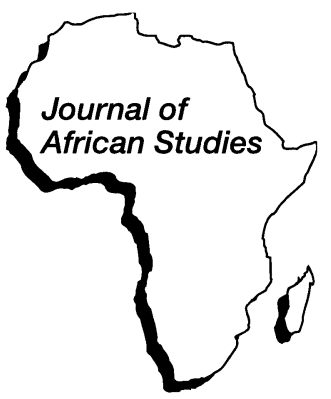

近畿大学農学部

鶴 田

格

\begin{abstract}
本論文の目的は，アフリカと東南アジアというふたつの地域の農民経済をめぐる議論を比較することをとお して，アフリカ農民の経済の特質を検討することである。ここでとりあげるのは，アフリカ的文脈で構想され た G. ハイデンの情の経済論と，東南アジア農村社会を舞台に議論されたJ. スコットのモラル・エコノミー 論である。どちらの概念も既存の政治経済学からはみおとされがちな共同体的なネットワークや価值に焦点を あてており，その背後にある家族の再生産の物質的基盤（サブシステンス）の重要性に注目している，という 共通点がある。他方で，両者のあいだには，それぞれの概念の内容が検討された事例地の歴史的・文化的なち がいにもとづく，微妙な差異があった。その差異は基本的に，アフリカ農民の道徳的規範はサブシステンスの 問題と密接にむすびついているのに対し，東南アジア農村ではこの両者が分離してひさしい，というちがいに 由来しているとかんがえられる。情の経済とモラル・エコノミーが示唆する共通の方向性に注目しながら，同 時にそれぞれの概念がもつ文化的な固有性を考慮することは，地域固有の文化と自立的な経済にもとづいたオ ルタナティブな社会開発のあり方（内発的発展）をかんがえるための有力な手がかりとなるだろう。
\end{abstract}

\section{はじめに}

サハラ以南のアフリカは，過去 25 年間に以前よりま ずしくなった唯一の地域である。とくにアジア諸国の目 ざましい経済発展とくらべて，アフリカにおける経済成 長のおくれはきわだっている。近年，先進国の政府や国 際機関は，アフリカでの貧困解消を国際社会のもっとも 重要な政策的課題のひとつとして位置づけ，債務の帳け しや援助額の増加を約束している。こうした政策は，た しかに飢餓，栄養不良，医療施設や公衆衛生制度の不備 などの, 個々の諸問題の改善に役だつにちがいない。し かし，これまでの歴史的経験がおしえるように，ODA などの開発援助がただちにアフリカ人の全般的な生活水 準の向上にむすびつくとはかんがえにくい。経済発展と は，社会経済全体のシステムの根本的な再編成のうえに はじめて達成されるものだからである。

20 世紀のアフリカ諸国では，植民地期から独立以降 の時期をへて現在にいたるまで，経済発展をうながすた めのさまざまな政策がとられてきた。その一方の極には

2006 年 12 月 13 日受付, 2007 年 2 月 7 日受理

連絡先 : $=631-8505$ 奈良市中町 3327-204
市場のはたらきを重視する自由主義的な政策があり，他 方の極には国家の強力な統制にもとづく社会主義的な政 策がある。たとえば東アフリカのタンザニアにおける換 金作物生産を例にとってみよう。そこでは植民地期に， ヨーロッパ人の主導のもとに，小農民による世界市場へ むけた商品作物 (コーヒー, 綿花など) の生産が進展した。 独立後のタンザニア政府は，そうした前代の遺産をひき つぎながらも, 1967 年以降は明白な社会主義政策をとっ てきた。その中心的な事業のひとつが, ウジャマー村政 策という集村化プロジェクトであり，これにより資本主 義によらない農業生産力の発展をめざしたのである。と ころが 1980 年代のなかばにはこうした社会主義政策の 破綻が明白となり，世界銀行等がおしすすめる構造調整 政策をうけいれ，市場を開放し経済の自由化をおこなっ た。ところが自由化をすれば商品作物生産が進展し農民 の生活が向上するであろう，という当初の見と扎しにも かかわらず，不安定な世界市場は農民の生活を安定にみ ちびくどころか, いっそう先のみえないものにしている。 こうして, 商業的農業という観点からみると, 自由主義 的政策も社会主義的（あるいは保護主義的）政策も，ど ちらも袋小路におちいっているとみることができる。そ してこうしたジレンマは，アフリカ諸国にかぎらず，現 在世界中の国民経済が打扔かれすくなかれ直面している 
問題なのである。

こうした状況のなか，自由市場にも国家の保護統制に もどちらにも依存しないコミュニティ・レベルでの経済 の形態，すなわちモラル・エコノミーについて論じるこ とが，いまほど重要である時代はないだろう。モラル。 エコノミーとは，その概念を東南アジアの農民社会に即 して検討した J. スコット（1999）によれば，農民の経 済的公正についての観念である。具体的には，（1）農 民の「生存維持（サブシステンス）の権利」の保障と, （2）互酬性の規範，というふたつの道徳的原理にもと づく，コミュニティ・レベルでの財の共有や取引のこと である。現代アフリカの文脈においてこのモラル・エコ ノミーについて論じることは, 次のふたつの点で重要で ある，と私はかんがえている。第一に，アフリカ農村に もおしよせるグローバル化した資本制経済の荒波のなか で，モラル・エコノミー的な関係は，市場も国家も提供 できない福祉「サービス」あるいはセーフティー・ネッ 卜を，現に人々に対して提供しているからである。第二 に，市場と国家のいずれにもたよることができない状況 のなかで，地域の経済的自立を射程にいれた社会開発の 方向をさぐる必要性がますますお抢きくなっているから である。アフリカ農村（や都市）の経済をモラル・エコ ノミーの観点から検討しなおしてみることは，この「内 発的発展」の議論に対して有用なヒントを提供するだろ う。

本論文では, 現代のアフリカ農村にとってモラル・エ コノミー的な観点がもちうる意義をさぐるために，まず アフリカ社会のモラル・エコノミー論とでもいうべき政 治学者 G. ハイデンの「情の経済」論をとりあげて検討 する。これは，アフリカ諸国が独立を達成してほぼ 20 年が経過した時点で，当初の楽観的な見通しにもかかわ らず農業の近代化がすすまなかった原因をアフリカ農民 固有の社会経済組織のあり方（情の経済）にもとめた議 論である。ハイデンの議論は，農村あるいは親族コミュ ニティ内部での生存維持の権利と互酬性の規範を重視し ている点で，スコットのモラル・エコノミー論とたいへ んにかよっている（上田, 2002: 235)。他方で，このふ たつの農民論には，それぞれアフリカ，東南アジアとい うちがった対象をとりあげているがゆえの，微妙な差異 があるようにおもわれる。

そこで本論文では，アフリカ的文脈に打ける八イデン の情の経済論をとりあげ，東南アジア的な文脈で議論さ れたスコットのモラル・エコノミー論と比較検討し，そ の共通性と差異をあきらかにすることをこころみる。こ こでは,そのふたつの議論を直接比較するだけではなく, それぞれの議論をめぐっておこなわれた論争をもとりあ
げつつ論をすすめていきたい。というのはどちらも同様 の立場からの批判をうけており，対立によってうかびあ がってくる共通の論点をはっきりさせることができるか らである。同時に，そうした対立の図式によって逆に隠 蔽される論点をも考察していく。それは，それぞれの地 域の歴史的文化的特性を検討することによってはじめて あきらかになるだろう。

ここで，本論にはいるまえに，あるひとつの単語につ いて読者の注意を喚起しておきたい。それは,アフリカ, アジアにかぎらずどこでも農民の経済を論じるときに重 要なキーワードとなる「サブシステンス」のことである。 サブシステンス (subsistence) は日本語にぴたりとあて はまる概念がないので訳すのがむつかしいのだが，通常 は「自給自足」「生存維持」などと訳される。英語の日 常語では「(物理的に) 生存ギリギリの」「やっと生活し ていけるだけの」という意味の，ネガティブなイメージ をもつ言葉であるが（たとえばサブシステンス・レベル とは最低生活水準を意味する)，カール・ポランニーや その影響をうけた人々がこの言葉を「市場経済」に対置 される概念として重視したことから（市場に依存しない という意味で) 自立性のニュアンスをおびることもある。 本稿では，このサブシステンスの意味を，今日的な文脈 にひきつけて再考してみたい。その議論の詳細はのちに ゆずるとして，ここではただ，以下でサブシステンスを あえて和訳せずカタカナ表記にする，ということをこと わっておく。

以下ではまず，アフリカ的文脈における情の経済論を 検討し，それをめぐっておこなわれた論争（「アフリカ 小農論争」）について検討する。つづいてスコットのモ ラル・エコノミー論とそれをめぐる反応を，もっとも率 直な批判者であったポプキンのそれを中心として検討す る。最後に，このふたつの概念の共通点と差異について 考察したうえで，こうした議論がもちうる現代的意義に ついて私自身の見解をのべてみたい。

\section{1. アフリカ的文眽における情の経済論}

\section{1. ハイデンのアフリカ小農論}

「アフリカは，農民がほかの社会階級にいまだに捕捉 されていない唯一の大陸である」(Hyden, 1980: 9)。八 イデンがその主著のひとつ『ウジャマーをこえて』で提 示しようとしたアフリカ農民像は，この簡潔な一文によ くあらわれている。植民地期から独立後の社会主義時代 にいたるタンザニア農村の変容を分析しつつ，ハイデン が達した結論は，世界の他地域と比較して，アフリカ農 
民はそれが近代国家と資本制経済から自立している点で きわめてユニークな性質をもっている，ということで あった。これは 1970 年代当時の政治経済学の分野で支 配的だった途上国論，とりわけマルクス主義的従属論に 影響された言説にまっこうから挑戦したものである。従 属論の立場からは，アフリカ農民とは，世界資本主義と その手先たる国内の支配階級にすくいがたいまでに従属 した存在でなければならなかった。ハイデンは，ある意 味でこの力関係を逆転させた見方をしめした。アフリカ では（政治的支配も市場もその前では無力にちかいとい う意味で）小農民こそが地域の政治経済におおきな影響 力をもっている，というのである。こうして彼は，アフ リカ農民の自立性をその「精髄としての特質にまでたか めた」 (Bryceson, 2000: 18-9) のである。

ハイデンによれば，アフリカ農民の自立性の基盤を 提供したのは，その生産と交換の形態，すなわち「小 農的生産様式 (peasant mode of production)」と「情の経 済 (economy of affection)」であった。アフリカ農民に 支配的な生産形態とされた小農的生産様式は, 次のよう な特徴をもっている。それはまず家族労働を主体とした 農業生産単位を基本とし, 単位間の分業は未発達であ る。各単位（=家族）は完全に自給自足的ではないにし ろ，農業生産の大部分はサブシステンスのためのもので あり, 利潤追求よりも家族の最低限の必要を安定してみ たすことが優先される。こうした生産形態の背景には, 簡素な農業技術にもとづく粗放的で生産性のひくい農業 がある。小農的生産様式は，家族の安定した再生産を優 先するため不確実性のたかい技術革新をなかなかうけい れないという保守的な性格をもつが，誰もが飢えずにい きる権利をあたえられるという点で平等主義的でもあ る (Hyden, 1980: 10-5)。アフリカでも一部で商業的農 業の発展がみられるが，それはあくまでそうした変化を 可能にする特殊な条件が存在した地域にかぎられている (Hyden, 1983: 5)。

こうした生産様式からうみだされる経済は，親族関係 や地縁的関係などの社会的紐帯にもとづく互酬的交換関 係すなわち「情の経済」である。それは「血縁，親族関 係, コミュニティもしくはほかの親近性（たとえば宗教） によってむすばれ組織化された集団のなかでの支援，コ ミュニケーション，相互作用のネットワーク」と定義さ れている (Hyden, 1983: 8)。社会規範にもとづく互助的 行為としての側面をもつ情の経済は，こうした集団内部 での資源や機会の再分配を可能にする。以下の引用によ くあらわれているように，それは生産よりも社会的再生 産（あるいは消費）につながる活動と密接にかかわって いる。たとえば「(貧しい農民は）政府から補助金をう
けて販売される生産手段を購入し，それをすぐに裕福な 隣人に転売し，えた現金を婚資，学費，葬式代，賄賂… 税，施し，供物などのためについやす」(Hyden, 1980: 18-9)。またギニア・ビサウの事例では，農村での余剩 生産物はまず不運な家族に分配され，次に宗教儀礼につ かわれ，ほかの財と物々交換されたあとに，最後にあ まった分が民間業者に販売される（Hyden, 1986: 691）。 ここでの要点は, こうした行為は決して浪費的でも非合 理的でもなく，親族やコミュニティの内部で自身の地位 を保持するための一種の投資であり，ながい目でみれば 自分の身や財産の安全を確保することにつながりうる, ということである。こうして情の経済は，一方でコミュ ニティの維持と再生産に貢献しながら, 他方で（生産的 目的に投資されるべき財が再生産的活動に投じられるた め）農業の近代化や経済発展を阻害する力としてはたら $<$ (Hyden, 1983: 17)。

アフリカに資本制的でない生産と交換の形態が存続し てきたことは，それまでも打くの論者によって指摘さ れてきた。たとえばアフリカ農村の親族組織とその再生 産の構造に焦点をあて，それが資本制経済とどのように 接合しているかを問題にしたメイヤスー（1977）の議 論などがある。しかし，ここでハイデンの所説をユニー クなものにしているのは，こうしたアフリカに特有の生 産と交換の様式（小農的生産様式と情の経済）が，市 場経済や近代国家と共存しているだけでなく，それに よって農民が市場や国家などの（農民を捕捉しょうとす る）外部の力からのがれることができる，とした点であ る (Hyden, 1980: 19-34)。自立的な農民的家族の再生産 がつづくかぎり，そのサブシステンスをおびやかすよう な国家もしくは市場からの圧力がはたらく場合には，そ れに対して抵抗するのは論理的帰結といえる (Hyden, 1980: 16)。それをもっとも鮮明にあらわしているのが， 社会主義国となった独立タンザニアのウジャマー村政策 (集村化政策) への農民の対応である。ハイデンは，こ うした開発政策にともなう政府の動員や要求を農民がい かにたくみに拒否してきたかを，くわしく描写している (Hyden, 1980: 96-155)。また利潤追求よりもサブシステ ンスの安定と社会的な考慮を優先する農民は, 資本制経 済の論理を全面的にうけいれることもない。たとえば農 民が換金作物生産や都市へのでかせぎをおこなって収入 の増加をもとめるのは，彼らが「経済合理的」だからそ うするというよりむしろ情の経済のネットワークのなか での自身の役割を拡大するためであり, この意味で彼 らは市場に「合理的」に反応しているのである（Hyden, 1983: 10)。

こうした国家（あるいは上層階級）と市場からの農 
民の自立性は，アフリカの「歴史的な特殊性」(Hyden, 1983: xiv）によるものであることをハイデンは随所で強 調する。アフリカは「エチオピアを例外として，政府に よる効果的な農業生産の統制の歴史をもたない」点で 世界でもユニークな存在である（Hyden, 1983: 10)。そ こでは，ヨーロッパやアジアとことなり，豊富な土地を 前提とした移動耕作が主流で，かんがいや鋤耕作などの 技術も発達しなかったために，土地の（したがって富や 権力の）集積がおこりにくく，結果として農民を恒常的 に控取する階級が不在のまま非集権的，平等主義的な社 会の性格が保持された。植民地期に商業的農業が導入さ れたが，それも小農的生産様式の基本的性格を根本的に かえることはなかった（Hyden, 1986: 681-3)。こうした 世界の他地域に類をみない歴史的経緯のために，情の経 済は単に現代アフリカの農村に根づよくいきのこってい るのみならず，政治や行政，製造業の分野においてさえ ふかく浸透し，こうした公的部門を骨妨きしている。 こうした論点は，農業発展のみならずひろく開発行政 一般について論じた著作『進歩に近道はない』(Hyden, 1983）に打いて，さらに系統だった形で展開された。

こうしてハイデンは，アフリカ農業の低開発の根本的 な原因を, 国際資本の謀略や政府の無能力にみるよりも むしろ既存の農民経済のあり方そのもの，つまり執拗に 持続する小農的生産様式と情の経済にもとめた。こうし た自立的な農民経済のために，農民は市場や国家の影響 力を拒否する選択肢を確保しており，さまざまな開発政 策や市場の誘惑からするりとのがれてしまう。こうして アフリカでは一種伝統的なものが現代の政治経済におお きな影響をおよぼしているにもかかわらず，従属論や新 古典派経済学などの既存の政治経済学のパラダイムでは こうした状況を把握できていない, と主張したのである。 なぜなら既存のパラダイムでは，アフリカにそもそも 「それ自身の社会的論理によってうごく」固有の生産様 式があるとはみなされてこなかったからである（Hyden, 1980: 20)。こうしてハイデンが当時の主流の途上国論, 開発論にはないあたらしい議論を提出したために，それ は，次にみるように，マルクス主義者からきびしい批判 をうけることとなった。

\section{2. アフリカ小農論争}

ハイデンの情の経済論とそれにもとづく「市場や国家 に捕捉されない農民像」は 1980 年代のなかばにマルク ス主義者によりはげしい批判にさらされた。一連の反論 と再反論は Development and Change 誌に揭載され, 論争 の当事者の一人である L. クリフはこれを「アフリカ小 農論争」となづけた。
議論の口火をきった N. カスファーは，その辛口の 論評のなかで，八イデンがアフリカ小農の自給自足性 （self-sufficiency）を強調したのは完全なまちがいである， と断じた（Kasfir, 1986)。カスファーによれば，そもそ も小農とは部分的に自立性をもつが，同時に外部の政治 経済的制度（国家と市場）にも打おきく依存（あるいは 従属）している存在である。まずアフリカ農民にとって 今や市場はなくてはならない存在である。税金のしはら いや生活必需品の購入に現金は必須になっているし, 生 産の面においても，彼らは市場価格にきちんと反応して 換金作物（それが食料作物であると輸出作物であるとを とわず）の生産をおこなっており，また農業における顀 労働が広範に存在する。ハイデンみずから小資本主義的 農民の存在をみとめているように, 農民の階層化は確実 におこっている。また農民と情の経済によってむすばれ ているとされる政治的パトロンは，むしろ上層階級とし て国家を利用し農民を搾取しているというべきである。 国家も，農民に対して税の徴収や農産物価格の統制と いった形で，つよい影響力を行使している。

このカスファーの批判に対してハイデンは，彼自身の 「捕捉されない農民像」を擁護する（Hyden, 1986）。力 スファーの誤解をとくために，八イデンは，自分はアフ リカの農民が自給自足的であるといったのではなく，サ ブシステンス経済と市場経済の双方に足をおきながら も，いざとなれば不安定な市場経済と国家のこうるさい 要求から「退出」する選択肢を確保している，といった のだと主張する。ここでハイデンが，比較史的な視点を あらためて強調しつつ論陣をはっていることに注目して おきたい。ハイデンによれば，アフリカ農民が他地域の 農民にくらべて「相対的に」自立している，という「構 造的な変則性」は，その特殊な歴史に由来する。先にも ふれたように，アフリカには（南北アフリカ，エチオピ アを除き）植民地期以前の国家が農民を従属させたこと はなく，また技術的制約と土地の豊富さという条件のた めに，農民の余㮃生産物を恒常的に搾取する固定的な階 級がうまれなかった。また資本制経済についても，それ は小農的生産様式を根本的に転換させることはなかった ので，それがほんとうの意味で支配的になっているとい うことはできない。アフリカにも個人主義的で企業家的 な農民がいるが，それは少数派であり，打打くの農民は 利潤をもとめるよりも自身のサブシステンスと社会関係 の再生産を優先する。だから，核家族化していない一般 のアフリカ農民について, 彼らが市場とのかかわりを もっているからといってすぐに個人主義的・「経済人」 的な行動を想定するのはあやまりである。

このハイデンとカスファーの論争は, クリフとウィ 
リアムズからのさらなる議論をよびおこした。クリフ （Cliffe, 1987）の議論の要点は，アフリカ農民は小農的 生産様式に特徴づけられる，といった本質主義的規定を するよりは，結局のところ彼らも資本主義的経済関係に むかっているのだから，どのような形で資本主義に包攝 されているのかを問題にしたほうがよい，というもので ある。彼は同時に歴史的経緯や生産技術の段階に関する 八イデンの主張も事実として不正確である, という。ク リフは小農的生産様式にかわる農民生産のモデルとし て，農民の小商品生産者としての性格に着目した「単純 商品生産」の概念を検討するが, それも事態を単純化し すぎているので，結局はそうした一般的モデルにたよる ことなく各事例それぞれの独自の文脈に即した多様性を 認識することが重要だという結論を提示するにとどまっ ている。ウィリアムズ（Williams, 1987）も，豊富な事 例的証拠をあげて，八イデンのアフリカ農民に関する本 質主義的規定を批判する。このような一般的な規定のし かたでは，アフリカ農村社会の長期にわたるダイナミズ 厶（都市への移民，資本主義の浸透，技術的進歩）とア フリカ小農の柔軟な適応能力が過小評価されてしまう, というのが彼の批判の要点である。

\section{3. 論争の再検討}

ここまでみたように，「アフリカ小農論争」では八イ デンとその反対者のあいだにはふかい認識のみぞがあ る。アフリカ農民経済の自立性を強調するハイデンに対 し，カスファー，クリフ，ウィリアムズの反論は，基本 的に，資本主義的もしくは階級的な関係に脱出不可能な までにからみとられた農民, という観点からおこなわれ た。そもそもハイデンの目的は農村の経済発展をさまた げるなにか固有の内的論理をさぐることにあり，それと 同時に慣行的な政治経済学的アプローチをみなおすよう よびかけることにあった。しかし, 彼の意図はしばしば 誤解され，単に「おくれた伝統的」側面を強調している ように解釈されてしまった。カスファーら反対者たちは みな，アフリカ農民がサブシステンス志向であり，あ る種の伝統的な社会的ネットワークによってむすばれて いる，という八イデンのかんがえに我慢がならなかった ようである。それは报そらく，ハイデン的な見解がひと むかしまえの「伝統が近代化を阻害する」といった素朴 な途上国停滞論を打もい扢こさせたからだろう（Cliffe, 1976: 112)。

ところで，歴史や生産技術に関する事実認識のまちが いに関する詮索はさておき，ここではハイデンの提示し た見方が，アフリカ農民の「経済」を理解するうえでは たして役にたつ方向をしめしているかどうかをかんがえ
てみよう。ハイデンは，アフリカ小農の生産や生活の内 的論理をさぐるこころみのなかで，彼らの完全には「捕 捉されない」自律性を強調するにいたったのに対して, カスファー，クリフ，ウィリアムズは，アフリカ小農は 市場にも国家にも「捕捉されている」という従属論的な 見方をとっている。たとえばカスファーらは，アフリカ 農民がすでに現金経済にまきこまれ，現に賃労働や農産 物販売が彼らの生活のかかすことのできない一部となっ ていることをもって「市場に捕捉されている」と主張し たかったようである。しかし，一定程度貨幣経済にとり こまれていることと, 自立するに十分なサブシステンス の基盤をもっている，ということは両立しうることでは なかろうか。たとえば完全に賃金労働に生活をたよって いることと，サブシステンスを補完するために賃金労働 や換金作物生産をおこなうことは，別のことである。私 のかんがえでは，ハイデンの主張の核心は，アフリカ農 民はもちろん部分的に国家や市場の影響をうけている が，サブシステンスのしくみ（それは物質的な基盤とと もに情の経済という社会的再生産のためのネットワーク をふくむ)の一番重要なところは手ばなしていない，と いうところにある。カスファーらは，アフリカ農民の経 済が資本主義や国家の影響によって再編成されていると みる点ではただしい。しかし，そのことによって農民の サブシステンスの基盤が完全にうしなわれたとかんがえ るなら，それはまちがっているということになる。

さらに，ハイデンの議論は，それがアフリカ農村社会 を独立の経営（生産）主体としての世帯の単なる集合体 という見方をこえた視点を提供している点で重要であ る。生産の観点からみると一見独立の単位のようにみえ る各世帯は, 消費や再生産の局面では複雑な財のやりと りによってむすばれており，それをハイデンは情の経済 とよんだのである。これに対してカスファーらは，生産 以外の局面ではまったくちがう生活をいとなんでいるか もしれないアフリカ農民を，あたかも他地域の商業的農 民と拉なじであるかのようにみなしている。彼らの理論 的立場は「生産的労働至上主義」とでもよぶことができ るだろう。つまり彼らの注意はまず労働の側面にのみ集 中し, さらに労働のなかでも生産的労働（貨幣価值をう みだす労働）にのみ着目するのである ${ }^{2)}$ 。ここには，八 イデンが示唆したような，生産の背後にある消費や再生 産等の生活全体をみるような視点がかけている。

もっともこの点に関しては，ハイデン自身の立論の仕 方にも問題がある。上述のようにハイデンは，アフリカ 農民に固有の社会経済組織を解明するにあたって，生産 面での「小農的生産様式」と，交換面での「情の経済」 をそれぞれ別個にとりだしたうえで分析を扔こなって 
いる。（20 世紀初頭のロシア農民をモデルとした）チャ ヤーノフの小農経済理論の影響が明白な「小農的生産様 式」の概念それ自体は, 独立した生産・再生産の単位と しての農家世帯「内部」のメカニズムを規定しているが， その「外部」にどのような社会関係が展開しているのか を何も説明しない（Bernstein, 1979: 422）。したがって, その「外部」のつまり世帯間の関係を説明するのにハイ デンは（アフリカに固有の社会的交換の形態として）情 の経済の概念をもちこんだのだろう。しかしこうした議 論のたて方は，杉村 (2004: 81-88, 378-383) がすでに 指摘しているように，あたかも孤立して生産・再生産を おこなう世帯群がまずあって，それらが(二次的に派生 する）情の経済によってむすばれている，というふうな 印象をあたえる。しかし後で引用する掛谷（1986）の 事例が示唆するように（ミクロ・レべルでみるかぎり） 事態をむしろ逆の順番で考察した方がよさそうである。 すなわち，アフリカ農民は孤立して生産をおこなったの ちに情の経済でむすばれるのではなく，逆に，情の経済 という社会関係を前提として, 生産やその他の活動をお こなっているとみた方が妥当なのではないだろうか。八 イデン自身が生産様式の概念は本来かならずしも生産の 仕方だけではなく, それが物質的社会的再生産, 財やサー ビスの循環や消費を組織する仕方をも含意するといって いる (Hyden, 1980: 12)。であるなら, 生産の様式と交換・ 再生産・消費の様式（情の経済）は本来不可分のもので あるということが，もっと強調されてもよかった。

ハイデンのアフリカ小農に関する議論は，しかしその 後一部の人類学者によって再評価される。ウォーターズ （Waters, 1992）は情の経済が説得的な議論であるとみと めたうえで，それをより一般的な文化社会学の枠ぐみの なかで議論しようとしている。杉村（2004）はみずか らのザイール（現コンゴ民主共和国）東部の熱帯雨林下 の焼畑農村に打ける調査体験にもとづき，アフリカ小農 のユニークさとサブシステンス経済の内的論理に関する ハイデンの議論（とりわけその社会的再生産と消費の側 面について）をさらに徹底した。杉村は，分与の経済を 象徵する共食慣行，混作というサブシステンス志向の農 業形態とその背後にある農民の論理, 家畜の社会的富と しての意義などについて詳細な検討を行い，それら諸側 面の結合のうえにいとなまれ再生産されていくひとつの 具体的な社会像を提示したのである。アフリカ農村では, 生産領域で生じる物質的富はさらなる生産のために蓄積 されるのではなく, 共食や婚資のやりとりといった消費· 再生産領域において共同体の成員に再配分されることに よって, 非物質的・社会的富として人間関係のなかに蓄 積される傾向が（たとえばアジア農村と比較して）つよ
い，と杉村は主張する。

じっさいには八イデンの視点は，こうした文化人類学 者の視点とまったく同一というわけではない。彼が自分 で説明しているように (Hyden, 1983: xiv, 4), ハイデン の立場は一種の唯物論（あるいは経済決定論）にもとづ いている。しかしそれは単線的な歷史的発展を想定する マルクス主義的唯物史観とはちがって比較史的な視角を とりいれており,そこからアフリカの「相対的な」ユニー クさという発想がでてきたのである。クリフやウィリア ムズも歷史的研究の必要性をうったえてはいるが，彼ら の近代主義的な議論（すべての社会はおなじ方向にむ かっているという前提にもとづく議論）からは，アフリ 力の歴史的特性はきえてしまう。一般に, 経済学者の議 論も人類学者の議論もどちらも比較の視点および歴史的 な視点がかけており，それは議論の混乱をもたらしてき ただけであると私はかんがえる。アフリカ独自の歴史的 文脈からうまれてきた情の経済論を，東南アジアのモラ ル・エコノミー論と比較しながら論じる必要があるのは, ここに理由がある。

\section{2. 東南アジア的文眽における モラル・エコノミー論}

\section{1. スコットのモラル・エコノミー論}

1976 年に発表された J. スコットの主著のひとつ『農 民のモラル・エコノミー』（スコット，1999）は，20世 紀前半に東南アジアの農民が扔こした反乱を題材に，そ の背景にある経済的公正にかかわる農民の価值観（モラ ル・エコノミー）をさぐろうとした仕事である。大恐慌 直後にビルマとべトナムでおこった農民反乱や，同時代 のフィリピンやタイの農村社会から事例をひきながら， スコットが注目したのは，サブシステンス志向の農民社 会にしっかりと根づいているふたつの道徳的原則，すな わち「互酬性の規範」と「サブシステンスへの権利」で あった（スコット，1999: 5-6, 204）。

スコットのおいた仮定のひとつは，生存ぎりぎりにち かいところでくらしている農民は，不安定な環境をこの まない，ということである。彼らの主な関心事はサブシ ステンスを安定的に維持できるかどうか，ということな ので，それを危険にさらすような冒険的行動を回避する 傾向があり，たとえば前例のない技術革新をうけいれる ことを（たとえ収入が向上する可能性があっても）躊躇 する(これをスコットは「安全第一の原則」とよぶ)。 第二に, 農民は村落共同体の一員として, ほかのメンバー あるいは有力者（パトロン）から種々の社会保障をうけ 
る権利をもつ。不作の年には，農民が行商をしたり，工 芸品をつくったり賃労働をしたりする道がひらかれてお り，また共有地で資材を獲得したり漁をしたりすること が社会的にみとめられていた。同時に, 賀窮時には親戚, 知人, 村社会, 有力者, そしてときには国家からの直接 的支援をうけるしくみがはたらいていた。たとえば親族 やパトロンからの援助, 地主による小作料の減免やその 他の支援, 国家による減税や備蓄米の提供, 公共事業で の雇用，などである（スコット，1999: 17-45）。

こうした伝統的な社会保障のしくみの背後にあるの が，スコットが「サブシステンスの倫理」とよぶ，農村 共同体の成員のサブシステンスは保障されるべきとする 道徳的規範である。そして，それが実際に社会的なしく みとしてなりたつときにはたらく原則が，互酬性の規範 である。それは村落レべルでの相互扶助のしくみから， 領主や地主と農民とのあいだにみられるパトロン・クラ イアント（保護者・被保護者）関係にまではたらいてお り，上記のようにさまざまなレべルにおいて，生存の危 機にさらされた農民にいきのびる道をあたえてきた。こ うした社会保障のしくみはまた，地主や領主に対する農 民の評価や選好と密接に関連している。たとえば, スコッ トによれば，農民は定額小作料や定額税よりも柔軟に変 動する小作料や税の方をこのむ。というのは，定額方式 は，豊作の年には農民に有利にはたらくが，不作の年に は徵収量が生存必要ラインをわりこむことでサブシステ ンスをおびやかす危険性がたかくなるからである。つま り彼らは，地主や国家によっていくら徵収されるかより も，いくら手元にのこるか，という方に関心をもってい る。だから農民にとって「よい地主」「よい国家」を判 断する基準は，その搾取量の大小にあるのではなく，(徴 収量に柔軟性をもたせたり直接的支援を扢こなったりす ることによって）いざというときに最低限の生存を保障 してくれるかどうか, にある。こうした議論から，農民 が上層階級や国家に対する反乱にたちあがるのは, 彼ら のサブシステンスが危機にさらされるかぎりにおいて のことである，という論点がみちびかれる（スコット， 1999: 46-72)。

しかしながら,こうした伝統社会のモラル・エコノミー は，19 世紀後半からはじまった本格的な植民地化と資 本制経済の浸透によって分断された。農業の商業化の進 展は，生産消費の両方の側面において農民を不安定な世 界市場に直結させることになった。植民地政府は従前の 領主よりきびしい税のとりたてをおこない，共有地の利 用や塩の売買などを規制することで，危機の際に農民が 自助努力によっていきのびるための選択肢をうばってし まった。人口圧力や開拓の進行のため共有地は減少し,
農民層の分解がすすみ，小作農の地主階級に対する交涉 力はよわまった。こうして植民地支配の強化, 市場経済 の浸透, 人口圧力の増大などが複合して, かつてあった 村落の社会保障のしくみは解体され，これが農民反乱の ひとつの要因となったのである（スコット，1999: 181, $192,240)$ 。

\section{2. モラル・エコノミー論争と 「日常的抵抗の形態」論}

スコットのモラル・エコノミー論は，とりわけ合理的 選択学派の立場にたつ政治学者 S. ポプキンが『合理的 農民』（Popkin, 1979）というタイトルの本を出版してい らい, アジア農民論の諸分野 (歴史学, 人類学, 経済学) でひろく議論の対象となった。ポプキンは，植民地期や それ以前のベトナムの農村社会の動態と農民運動を題材 として, スコットや他の「モラル・エコノミスト」が唱 道した共同体的な農民像に異をとなえた。彼の主張は， スコットとはまったく反対に，ベトナム農民といえども 合理的選択をおこなう個人主義的な経済人である，とい う観点からおこなわれている。つまり，スコットが非進 取的で平等主義的, 調和的な農民像を提示したのに対し て，ポプキンは，農民は個人的な利害計算を行動基準と しており，機会さえあれば収入の増大や地位の向上をの ぞむ合理主義者であるとした。たとえ調和的にみえる植 民地期以前のベトナム農村でも, 自己の政治的経済的利 害を追求する利己的な個人間の衝突がつねにおこってい た，というのである。このポプキンの批判は，よかれあ しかれ，その後のモラル・エコノミーにかかわる議論の パターンを形づくった（Keyes, 1983)。

じっさいには，ポプキンの批判は，モイズがすでに 指摘するように，スコットのモラル・エコノミー論の たいへん簡略化されたかたよった像にもとづいてい る（Moise, 1982）。スコットの著作を注意ぶかくよめば わかるように, 彼は決して伝統的な農村生活をロマン ティックにえがいているわけではない。またスコットは, 自身のモデルが完全に適用できるのは，サブシステンス がさしせまった問題となるような状況におかれた農民の 場合にかぎってであって，そうでない場合（さしたる危 険をおかすことなしに生産を拡大したり収入をふやした りする機会にめぐまれている場合）にはあてはまらない だろう，とわざわざことわっている（スコット，1999: 27-9)。じっさい, 1970 年代以降の東南アジア農村はい わゆる緑の革命などの影響もあり飛躍的な経済発展をと げた。そうした時代背景のなかで，おおくの論者がス コットの提示した非進取的で市場の不安定性をきらうよ うな農民像の有効性に疑問を呈したのは当然のなりゆき 
だったともいえる（北原，1985: 37-58)。（スコットがえ がくように） 1930 年代にすでに危機的な状況にあった 東南アジア農村のモラル・エコノミーは, 戦後の急激な 経済成長のなかでサブシステンスの問題から遊離してし まい, いわば単なるモラルと単なるエコノミーに分解し てしまったのである3)。

こうした状況の変化は，スコット自身の仕事の変化に も反映しているようにおもわれる。彼がその後発表した 著作『弱者の武器』（Scott, 1985）においては，モラル . エコノミー論でとりあつかったような直接的な反乱では なく，もっと日常的で隠微な農民の抵抗の仕方を「抵抗 の日常的形態 (everyday forms of resistance)」というキー ワードのもとに論じている。マレーシアの農村の日常の なかで，農民がサボタージュ，ごまかし，窃盗，噂話な どの目だたない間接的な方法を通して，農村レべルでの 政治経済的支配に対抗しようとするさまを詳細にえがい たのである。この「抵抗の日常的形態」は，スコット自 身も言及しているように，タンザニアの文脈における八 イデンの「捕捉されない農民」をおもいおこさせる (Scott, 1985: 31, 302)。そこでは, 農民が，やはりサボタージュ やごまかしなどの手段をつかって，ウジャマー政策を強 制しようとする国家官僚からたくみにのがれていた。し かし 1970 年代末のマレーシアの稲作農民は，そのサブ システンスの基盤において，同時代のアフリカ農民より も市場や国家に依存している(つまり「捕捉」されている) 度合がはるかにつよかったことはうたがいない。そこで は，国家のかんがい水路整備事業によって可能となった 緑の革命が，機械化や小作慣行の変化，外部資本の流入 などをもたらし，村内の既存の人的依存関係をほりくず してしまっていた。農村内部の階級的関係にとくに注 意を集中したスコットは，このあたりの事情を「(貧農 の）搾取から周辺化へ」という言葉でたくみに表現して いる（Scott, 1985: 76）。つまり（機械化のおかげで）い まや地主にとって役にたたない存在となってしまった唄 農は，地主との搾取的な㕍用関係すらむすぶことがなく なって，単に（経済的な意味で）周辺部に扎いやられて しまったのである。こうして，すでにモラルと（サブシ ステンス)エコノミーが解体してしまった状況のなかで, スコットはモラル（文化）の側面に注意を集中し，その 結果, 前作より詳細な農民価值と行動の記述をおこなっ たのだとおもわれる。経済がますます自律的な領域とし て拡大していくなかで，前著で提起したような「農民の 道徳的世界 (moral universe)」(スコット, 1999: 282-3) の探求を, より文化論として精緻化するという方向に, 彼はむかわざるをえなかったのである。

\section{3. モラル・エコノミーと情の経済のあいだ}

\section{1. モラル・エコノミーと 情の経済の共通点と差異}

情の経済論とモラル・エコノミー論は, どちらも社会 科学者 (マルクス主義, 新古典派をとわず既存の政治経 済学の研究者）からはわすれさられがちな側面，つまり 国民国家や資本制経済にどっぷりつかった目からみおと されがちな共同体的なネットワーク, 人間関係, 価值（と りわけ互酬性の規範）に焦点をあてており，その背後に ある（再生産の）物質的基盤としてのサブシステンスの 重要性に注目している点で共通している。どちらも, 経 済合理主義に対して, 地域文化の文脈での共同体的価值 の合理性を擁護（あるいは強調）している。しかしどち らの議論も, 一方はマルクス主義者, 他方は合理的選択 論者からのはげしい攻撃をうけ，経済合理性の神話ある いは生産的労働至上主義にもとづく「進歩」への信仰が いかにかたくななものであるかをしめした。

こうした共通点にもかかわらず，アフリカ農村での経 験をもとにねりあげられた概念である情の経済と, 東南 アジア農村を舞台に検討されたモラル・エコノミーをく わしくみてみると，それぞれの地域の歴史的，文化的特 性に由来する微妙なちがいがあるようにおもわれる。ま ず歴史的な側面について簡単に検討してみよう。打 ざっぱにいって，西欧の植民地主義と資本制経済の影響 が農民レベルにおいて広範におよぶのは，一見すると東 南アジア (19 世紀後半) においてもアフリカ (20 世紀 初頭）においても，時期的に打打きなちがいがあるわけ ではない。しかし，当時アフリカには西欧の侵略に有効 に対抗できるような国家的統合がほとんどみられなかっ たのに対し，東南アジアには $9 \sim 13$ 世紀に形成された 中世的国家のながれをひく強力な国家群が存在した。そ こでは官僚制と軍隊にもとづく統治システムが確立され ており（一部の国家は対外通商をもみずから組織してき た，農民を従属階級とする複雑な身分社会がすでに存 在していた（北原，1985: 5)。それでも近代以前はまだ 一定程度の自由と自立性をたもっていた農民は，前述の ように，植民地期を通していっそう従属的なよわい立場 においこまれていく。たとえば 20 世紀初頭の東南アジ アの農民の不安定性に言及しながら，スコットは，農民 のかんがえる身分序列は，所得の大小にかかわらず小自 営農，小作農，年単位（あるいは季節単位）で契約する 農業労働者, 日やといの農業労働者の順番になっていた という。なぜなら，後にいくほどサブシステンスの保 障が不確実になっていくからである（スコット，1999: 46-51)。これは単に農民の職業的選好がかならずしも平 
均収入の多寡によって決定されるわけではない，という ことをしめしているだけでなく，20 世紀初頭の東南ア ジアの農村社会は，現代のアフリカ農村よりもはるか に階層化がすすんでいたことをもあらわしている。こ うして，ハイデン自身も指摘するように (Hyden, 1987: 679-80), 東南アジアではアフリカよりずっと以前から 農民が国家や市場に「捕捉されて」おり，それら外部の 制度やそれを人格化している中間権力者に対する防衛 的，対抗的なうごきを結集したのがモラル・エコノミー だった。スコットによって提起されたモラル・エコノ ミ一論は, だから, 共同体外部の権力による農民の搾取 と，それに対する農民の怒りを主題としているのに対し， 情の経済は，農民がそうした外部の権力からのがれるユ ニークな能力をしめしているのである。

こうした歴史的経緯の帰結として,モラル・エコノミー の概念は，農民と上層階級の相互依存的あるいは相互 対抗的関係, という意味あいをつよくともなう場合がお おく，それが主として水平的社会関係にかかわる情の経 済との文化的な差異のひとつとなっているようにおもわ れる。両者の文化的な差異をあらわすもうひとつの側面 は，消費の共同性と互酬性にかかわる側面である。杉村 （2004）は，アフリカ農村では，消費する食料や現金の わかちあいという行為が日常的にみられる点を強調して いる。つまりアフリカ農民の打打くは，サブシステンス の相当部分をほかの世帯に依存しているということにな る。他方で，すでに論じたように現在の東南アジア農民 はそのサブシステンスを隣人よりも市場（場合によって は国家のつよい介入）に打打きく依存している。その結 果, 生産抢よび消費の単位としての世帯の独立性が非常 にたかくなって打り，私のしっているタイの稲作村の事 例では，世帯は基本的に必要な物資を（主食であるコメ ですら）市場から調達し，世帯間で財の互酬的なやりと りや共同消費をおこなう機会は，ほぼ儀礼的な場面にか ぎられる。

こうした消費の共同性にかかわる顕著なちがいに注目 して，杉村（2004: 415）は，財の共有ややりとりの背 後にある両地域の互酬性の規範について，東南アジアの それはサーリンズ（1984：223-85）のいう「均衡のと れた互酬性」として位置づけられるのに対して，アフリ カのそれは「一般化された互酬性」と性格づけられる, という指摘をしている。つまりアフリカでは，きびしい 等価性を追求する東南アジアとくらべて互酬性のあり方 が打らかで，取引のバランスに対してこまかい配慮が はらわれることはない，というのである。私はこれにく わえて，次の二点を指摘しておきたい。第一点目は，そ うしたちがいがもしあるとすれば，東南アジアの均衡の
とれた互酬性は，市場経済の浸透によって互酬性がサブ システンスの問題とむすびつかなくなったことのひとつ の帰結ではないか，ということである。そこでは，互酬 的交換が市場での経済的交換の論理に影響されたものと なり，結果として交換の等価性にこまかい注意がはらわ れるようになっている（Tsuruta, 2004）。それに対して アフリカでは, 互酬性がいまだにサブシステンスと密接 なかかわりをもっているために，つまり必要量をあたえ たり獲得したりすること自体が重要なので，交換量の等 価性への配慮が二次的なものとなるのではないだろう か。

第二点目は，東南アジアの人間関係における互酬性に おいては，仏教やイスラーム教などの民衆宗教による意 味づけがなされる場合をのぞいて（あるいはその場合 ですら)，世俗的な意味で他人へのきめこまやかな配慮 が重要な要素となるのにくらべて（Tsuruta, 2004: 106), アフリカの互酬性は, 執拗にのこる超自然に対する信仰, この場合他人からの呪いへの恐怖におお打きく影響されて いるのではないか, という点である。「消費の共同」が「呪 術への恐怖」にささえられているさまを見事にえがきだ したのが，掛谷（1986）である。掛谷が 1970 年代に調 查したタンガニーカ湖畔にすむトングウェ人の生活にお いては，「最小生計努力」とよぶことができるような自 給志向のサブシステンス経済の背後に, 世帯や集落をこ えた食料の贈与によって，世帯（集落）ごとの生産量の 不均衡を平均化する傾向 (「食料消費の平均化」) がある。 そうした一見平等志向にみえるような互酬的なやりとり の背後には，じつは，打打くのものをもつ村人へのねた みや，分与をこばむ者へのうらみに起因する呪いへのお それがひそんでいた。

\section{2. モラル・エコノミーと情の経済の現代的意義}

スコットとハイデンの農民論のあいだには，もうひと つ重要なちがいがあった。情の経済の概念は, アフリカ 農村の経済発展に関するハイデンのふかい関心と密接な 関連をもっていたが，スコットのモラル・エコノミー論 は主として歴史的な事実の解釈をめぐってのものだった ため，それは現代の経済発展の問題には直接にはむすび つかないようにみえる。しかしながら，昨今の経済のグ ローバル化によって, 現在世界中の農民のおかれている 状況は，スコットがえがいた 20 世紀初頭の東南アジア 農民の状況に，非常ににかよってきているように抢もわ れる。100 年前とおなじ様に, 現在どこの国の農民（や 労働者）でも，国家による保護的規制がつぎつぎにとり はらわれたことによって, 資本制経済の圧力を肌身に直 接感じるようになっているはずである。とりわけ単一の 
商品作物に依存する農民たちは，競争にまけて一気に生 存ぎりぎりの状態までおちいる危険につねにさらされる ようになった。こうして，すでに大部分の東南アジア農 民からは過去のものとおもわれてきた「サブシステンス」 の問題，つまり市場や国家にたよらずに生活をたてなお し，いきのびることが，アフリカのみならず，ふたたび 人口のおおくにとって問題となる状況が間近にせまって いる。

末原 (1990: 271, 289) や杉村 (2004: 370-381) は, すでに（消費財の購入や病気の治療など）一定の生活水 準を維持するのに現金が不可欠となっていたアフリカ農 村での調査経験をふまえて, サブシステンスの意味を, 単に生物学的な意味での生存維持ではなく, より人間ら しい生活の基盤として，つまり現金経済にささえられる 部分や社会的文化的関係をもふくめた概念として再考す る必要性を指摘している。こうしたサブシステンスの意 味の再検討をすすめるうえで示唆的なのは，現代産業文 明の批判者として著名な思想家イヴァン・イリイチの考 察である。イリイチの論考に扔いては，サブシステンス は，市場にも官僚的制度にもたよらずに自律的にいとな まれる生活，という積極的な意味でつかわれており，訳 者の玉野井芳郎はこれを「人間生活の自立・自存」と訳

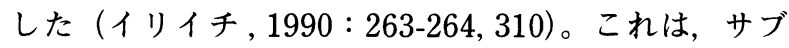
システンスをおくれた退嬰的なものととらえる従来の意 味あいからすると，180度の価値転換である。また著名 なフェミニスト理論家・実践家の M. ミースらは，同 様の視点から，サブシステンスという概念を，資本制経 済とそれがうみだす抑圧的状況をのりこえるためのあた らしい社会構築の原理として重視している。ミースらの いうサブシステンス (生産) とは，人間が（自然と調和 しながら）自己と家族の生命と生活を維持し再生産して いくのに本当に必要な諸活動, つまり「妊娠, 出産か ら, 生産, 食料の加工や準備, 衣服の用意, 家事, 掃除 までを含み, さらに感情的および性的な欲求の充足まで を含む人間の多様な諸活動」を意味している(ミース他， 1995: 80)。

先に私は，モラル・エコノミーと情の経済はどちらも サブシステンスの重要性を強調する点で共通していると のべたが，その今日的意義を理解するには，こうしたサ ブシステンスの意味のよみかえが必要になるだろうとお もう。そうすることによってはじめて，ハイデンのいう 「捕捉されないこと」の積極的意味を理解することがで きるし, またモラル・エコノミー論(あるいは情の経済論) と内発的発展論の対話が可能となる。だから, ここで重 要なことは，サブシステンスという概念を（カスファー がそうしたように）単なる「自給自足」という意味にす
りかえて矮小化してはならない, ということである4)。 それは, 人間が人間らしく自立していきるための物質的・ 精神的基盤なのであり，コミュニティの人間関係によっ てささえられ，きずきあげられるもの，と解釈されるべ きである。

そもそもハイデンや杉村がえがく農民像にもとづいて かんがえれば，アフリカ農民のサブシステンスは，(必 要な食料の調達というように）まさに物理的な意味でコ ミュニティ内部の他人に依存しているのだから, 必然的 に社会関係をその概念のうちにふくむものでなければな らない。つまり情の経済は，アフリカ農民のサブシステ ンス生産・再生産の不可欠な一部を構成しているのであ る。スコット (1999: 11, 21, 214) もサブシステンス(の 水準) が生理学的な生存という客観的な側面と同時に, 社会的文化的側面をもっていることを指摘している。に もかかわらず，そこにはそれがそもそも日常においても モラル・エコノミーのネットワークに維持されていると いう視点は希薄である。また，外部勢力に対する対抗と いう意味あいのつよいモラル・エコノミーとことなり, 八イデンは情の経済を，人々が単にいきのびたり社会を 維持したりするだけでなく,社会開発につながる積極的・ 創造的な活動をにないうるものとしてとらえているとい う点も，みのがしてはならないだろう (Hyden, 1983: 9, 11-6 ならびに本号所収のハイデン論文参照)。それはサ ブシステンスの概念が含意するしたたかさ,たくましさ， 創造性に注目するミースらの次のような視点と共鳴する ものがある。それは「生活を創造し維持していく性格」 をもつとともに,「必要の範囲内での自由, 幸福, 自己 決定…ねばりづよさ，根気，抵抗への意志，下からの視 点,ゆたかな世界」などをも含意するとされている（Mies and Bennholdt-Thomsen, 1999: 12,19)。

\section{結論}

ここまでアフリカ農村の文脈において展開されたハイ デンの「情の経済」論と, 東南アジア的文脈のもとで構 想されたスコットの「モラル・エコノミー」論を対比し ながら論じてきた。両者は，近代社会に特有の価値であ る経済合理主義あるいは生産至上主義に対して，近代化 の多大な影響をこうむりながらも存続してきた共同体的 価值に焦点をあてる，という点で共通している。それは 単に文化的な価值にとどまるものではなく，サブシステ ンス（第一義的には生存の物質的基盤）に直接かかわる という意味で「経済」的なものである。他方で，両者の あいだには，それぞれの概念の内容が検討された事例地 
の歴史的·文化的なちがいにもとづく,微妙な差異があつ た。

これらの概念は，既存の市場や国家の枠ぐみのもとで 物質的な富の増大犬゙けをめざすようなせまい「経済発展」 のかんがえ方を相対化するうえで有効である。しかしこ こで両概念の共通点だけに注目すれば，たとえば非市場 的な社会関係なら何にでもこれらの概念があてはまるこ とになってしまい，そのことによって，個別事例の歴史 的文化的背景を考慮にいれた分析ができなくなる危険性 がある（Lemarchand, 1989; 上田，2002）。さらに内発的 発展の思想が示唆するように，世界中のどの地域も固有 の発展形態をもつべきだとすれば, 情の経済論と(スコッ トの）モラル・エコノミー論の歴史的・文化的差異にも 注意をはらわなければならない。私たちは，これらの概 念に性急に共通の固定的な意味をあたえて満足するより も，それらはあるべき発展をかんがえるのに必要な「方 向」を示唆している，とゆるやかにかんがえるべきなの だろう。

この方向をさししめすものとして本稿で注目したの は, どちらの概念も重視していたサブシステンスである。 サブシステンスを, 生物学的欲求の充足というその本来 の意味とともに，人間の人間らしい生活の自立的な再生 産という意味をふくむものとかんがえてみよう。こうし てサブシステンスに積極的な意味をあたえることによっ て，かつてイリイチ(やミースら）がきりひらいた議論 の地平に接続することができる。すなわちサブシステン スを単に物質的欲求の充足という域をこえて，教育，医 療，ケア，生命の再生産，言葉，交通など生活のさまざ まな領域における人間の自立の問題として議論できるよ うになる。そしてこれらは，私たち日本人こそがいま真 剣にかんがえ解決しなければならない問題群ではないの だろうか。こうしてみると，資本制経済のグローバルな 展開が（まさに物理的な意味で）人類のサブシステンス の基盤そのものをほりくずそうとしている現在，とおい アフリカの農村の経済について論じることが，そのまま 現代日本の諸問題にも直接むすびついてくるように，私 にはおもわれてならない。

\section{注}

1）本稿は，2005 年 8 月 18-20 日にダルエスサラーム大学で おこなわれた国際会議（Contemporary Perspectives on African Moral Economy) において発表した論文（"Between Moral Economy and Economy of Affection”）に大幅な加筆修正をお こなったものである。

2 ）生産的労働（とその対概念としての非生産的労働）につい
ては，アダム・スミス以来，論者によってさまざまにことな る定義がなされてきた。しかしここでは，さしあたりウォー ラーステイン (1997: 22-23) のごく簡潔な定義にしたがって おく。すなわち生産的労働とは現金収入をえるための労働で, 非生産的労働とは基本的にサブシステンスのための活動であ る。

3) 同様の主旨のことをハイデンは, 東南アジア農民のいわ ゆるモラル・エコノミーは, 経済構造とつながりがあった以 前とちがって,「純粋に道徳的なもので, 経済構造の裏づけ のない，単に上部構造的な表現にすぎない」とのべている (Hyden 1980: 211)。

4) ハイデンは，アフリカ小農論争を総括した論文（Hyden 1987）のなかで，自分がつかった「サブシステンスの法則」 という言葉が，アフリカ小農が自給自足しているという印象 をあたえ誤解をまねいたようなので，そのかわりに「消費優 先の規範 (consumption imperative)」という表現をつかう方 が適切かもしれない，とのべている。しかしサブシステンス の意味をここでいうように定義すれば，そうしたいいかえの 必要はない。

\section{引用文献}

Bernstein, H. (1979) “African Peasantries: a Theoretical Framework”, The Journal of Peasant Studies 6: 421-443.

Bryceson, D. (2000) "Peasant Theories and Smallholder Policies: Past and Present", In D. Bryceson, C. Kay and J. Mooij (eds.), Disappearing Peasantries?, London, Intermediate Technology Publications, pp. 1-36.

Cliffe, L.(1976) "Rural Political Economy of Africa", In P. Gutkind, and I. Wallerstein (eds.), The Political Economy of Contemporary Africa, Beverley Hills, Sage Publications, pp. 112-130.

- (1987) "The Debate on African Peasantries", Development and Change 18: 625-635.

Hyden, G. (1980) Beyond Ujamaa in Tanzania: Underdevelopment and Uncaptured Peasantry, London, Heinemann.

- (1983) No Shortcuts to Progress: African Development Management in Perspective, London, Heinemann.

- (1986) "The Anomaly of the African Peasantry", Development and Change 17: 677-705.

- (1987) "Final Rejoinder”, Development and Change 18: 661-667. イリイチ, I. (1990)『シャドウ・ワーク』(玉野井芳郎・栗原涁訳), 岩波書店（同時代ライブラリー）.

掛谷誠 (1986) 「伝統的農耕民の生活構造」伊谷純一 郎・田中二郎編『自然社会の人類学』アカデミア出版会, pp.218-248.

Kasfir, N. (1986) “Are African Peasants Self-sufficient?", Development and Change 17: 335-357.

Keyes, C. F. (1983) "Introduction, Peasant Strategies in Asian Societies: Moral and Political Economic Approaches - A Symposium", Journal of Asian Studies 42-4: 753-768. 
北原 淳（1985）『開発と農業 : 東南アジアの資本主義化』世 界思想社.

Lemarchand, R. (1989) “African Peasantries, Reciprocity and the Market: The Economy of Affection Reconsidered", Cahiers d' etudes africaines 113: 33-67.

メイヤスー, C. (1977) 『家族制共同体の理論』（川田順造・原 口武彦訳), 筑摩書房.

ミース, M. , ベンホルトートムゼン, C. フォン・ヴェールホ フ（1995）『世界システムと女性』（古田睦美·善本裕子訳）, 藤原書店.

Mies, M. and V. Bennholdt-Thomsen (1999) The Subsistence Perspective: Beyond the Globalised Economy, London, Zed Books.

Moise, E. E. (1982) "The Moral Economy Dispute", Bulletin of Concerned Asian Scholars 14-1: 72-77.

Popkin, S. L. (1979) The Rational Peasant: the Political Economy of Rural Society in Vietnam, Berkeley, Los Angeles, and London, University of California Press.

サーリンズ, M.（1984）『石器時代の経済学』(山内䞟訳)，法 政大学出版局.

Scott, J. C. (1985) Weapons of the Weak: Everyday Forms of Peasant
Resistance, New Haven and London, Yale University Press.

スコット，J. C. (1999)『モーラル・エコノミー：東南アジア の農民叛乱と生存維持』(高橋彰訳), 勁草書房.

末原達郎（1990）『赤道アフリカの食糧生産』同朋舎.

杉村和彦（2004）『アフリカ農民の経済』世界思想社.

Tsuruta, T. (2004) "Changing Values in Reciprocity: A Case Study of Commercialized Thai Farmers", Tanzanian Journal of Population Studies and Development 11-2 (Special Issue: African Economy of Affection): 103-116.

上田 元 (2002)「東アフリカ小農社会のモラル・エコノミー をめぐる諸論」高根務編『開発途上国の農産物流通一アフリ カとアジアの経験』アジア経済研究所, pp.215-242.

ウォーラーステイン，I.（1997）『史的システムとしての資本 主義』(川北稔訳), 岩波書店.

Waters, T. (1992) "A Cultural Analysis of the Economy of Affection and the Uncaptured Peasantry in Tanzania", The Journal of Modern African Studies 30-1: 163-175.

Williams, G. (1987) "Primitive Accumulation: the Way to Progress?” Development and Change 18: 637-659.

\title{
(Summary)
}

\section{African Peasant Economy from the Moral Economy Perspective}

\author{
Tadasu TSURUTA \\ Faculty of Agriculture, Kinki University
}

This paper aims to review theories of peasant economy in Africa and Southeast Asia from the comparative perspective. Focusing on Goran Hyden's notion of 'the economy of affection,' I will examine his argument on African peasantry in comparison with the 'moral economy' thesis developed by James Scott in the context of Southeast Asian peasantry. One can find theoretical similarities in the two theses, in the sense that both address themselves to communal and consumptionoriented values inherent in subsistence economy of peasants, in stark contrast to production-oriented utilitarianism which characterizes industrialized economy. At the same time, their arguments differ in details over how the moral-based economy actually works in peasant life, reflecting significantly different historical and cultural background of each region. These similarities and differences have important implications for endogenous development, which places a special emphasis on indigenous culture of each community, as an alternative to unsustainable models of economic development. 